\title{
Caucasian clover/ryegrass produced more legume than white clover/ryegrass pastures in a grazed comparison
}

\author{
A.D. BLACK ${ }^{1}$, K.M. POLLOCK ${ }^{1}$, R.J. LUCAS $^{1}$, J.M. AMYES ${ }^{1}$, D.B. POWNALL ${ }^{1}$ \\ and J.R. SEDCOLE ${ }^{2}$ \\ ${ }^{1}$ Soil, Plant and Ecological Sciences Division, PO Box 84, Lincoln University, Canterbury \\ ${ }^{2}$ Applied Management and Computing Division, PO Box 84, Lincoln University, Canterbury \\ ${ }^{1}$ Blacka1@lincoln.ac.nz
}

\begin{abstract}
The potential of caucasian clover to improve the legume content of lowland New Zealand pastures should result in enhanced animal performance. Liveweight gains from eight flocks of ewe lambs rotationally grazing irrigated ryegrass pasture with caucasian or white clover at two levels of soil fertility (Olsen P values 10 or 22) were compared during years 2 (1998/1999) and 3 (1999/2000) of an ongoing grazing experiment in a lowland environment. Clovers were sown in December 1996 and ryegrass in March 1997 into the pure clover swards. Lamb liveweight gains were similar in year $2(1130 \mathrm{~kg} / \mathrm{ha} / \mathrm{yr})$, but in year 3 , gains were greater on pastures sown with caucasian than on those sown with white clover (1290 vs. $1110 \mathrm{~kg} /$ ha/yr). Spring liveweight gains per head per day averaged $170 \mathrm{~g} / \mathrm{hd} / \mathrm{d}$ in year 2 , and in year 3 were greater from caucasian than white clover pasture (180 vs. $160 \mathrm{~g} / \mathrm{hd} / \mathrm{d})$. Caucasian clover pastures had more legume on offer than pastures sown with white clover in year $2(26 \%$ vs. $17 \%)$ and year 3 (19\% vs. $12 \%$ ). In year 3, 39\% of the total legume on offer in caucasian clover pastures was volunteer white clover. Soil fertility had little influence on results. Early years of this grazing experiment showed that caucasian clover can establish as well as white clover if sown alone, and that sowing caucasian clover can result in lowland pastures with an increased total legume content which may improve liveweight gains.
\end{abstract}

Keywords: legume content, Lolium perenne, pasture production, sheep liveweight gain, Trifolium ambiguum, T. repens

\section{Introduction}

Caucasian clover (Trifolium ambiguum) has demonstrated persistence and competitiveness in New Zealand hill and high country pasture (Allan \& Keoghan 1994; Scott 1998; Woodman et al. 1992). Caucasian clover is now also recognised as having potential in lowland intensive farming systems where white clover (Trifolium repens) suffers abiotic (drought, high soil-surface temperatures) and/or biotic (grass grub, nematode, virus, weevil) stress. For example, caucasian clover has survived summer drought and nematode attack better than white clover on light volcanic soils in coastal Bay of Plenty (Watson et al. 1998; Watson et al. 1996a). Where perennial grass competition presents the major stress on pasture legumes, caucasian clover has also been more productive than white clover in lowland irrigated (Moss et al. 1996) and unirrigated pastures (Black \& Lucas 2000).

The ability of caucasian clover to improve the legume content of lowland pastures should result in corresponding increases in animal production (Askin et al. 1987; Harris et al. 1997; Stevens et al. 1993). Caucasian clover nutritive value and acceptability by livestock are similar to white clover (Allinson et al. 1985; Hill et al. 1995), and liveweight gains from lambs grazing pure stands are comparable to those from birdsfoot trefoil (Sheaffer et al. 1992). However, livestock production from caucasian clover and white clover in mixtures with perennial grass have not been compared.

The objective of this research was to compare liveweight gains from lambs grazing perennial ryegrass (Lolium perenne) pastures sown with either caucasian clover or white clover at high or low soil fertility. Results are presented from the second (year 2) and third (year 3) spring, summer, autumn seasons of an ongoing grazing experiment.

\section{Materials and methods}

The grazing experiment at Lincoln University, on a Templeton silt loam, used a $2^{2}$ factorial design in a Latin square arrangement where ryegrass pastures sown with caucasian clover or white clover were compared at high or low soil fertility with eight replicates. Eight flocks of lambs each grazed four plots of the same treatment so that there were two animal replicates of the $2^{2}$ design.

Hexaploid 'Endura' caucasian (6 kg/ha) or 'Grasslands Demand' white ( $2 \mathrm{~kg} / \mathrm{ha}$ ) clovers were sown in December 1996 into 0.04 ha plots. Superphosphate $(9 \% \mathrm{P}, 12 \% \mathrm{~S})$ was applied at $1 \mathrm{t} / \mathrm{ha}$ to the 16 high- 
fertility plots after sowing. Lime was applied at $1 \mathrm{t} / \mathrm{ha}$ to all plots after sowing. Caucasian clover seed was inoculated heavily with the specific Rhizobium strain ICC148 (Pryor et al. 1998). Post-emergence herbicides were used to control dicotyledonous weeds. 'Grasslands Ruanui' zero endophyte (Neotyphodium lolii) ryegrass seed was direct-drilled at $15 \mathrm{~kg} / \mathrm{ha}$ into the pure clover turf in March 1997. The high-fertility plots had an Olsen P of 22 and the low-fertility plots had an Olsen $\mathrm{P}$ of 10 in May 1998 (Table 1). Sulphur superphosphate $(8 \% \mathrm{P}, 19 \% \mathrm{~S})$ was applied at $250 \mathrm{~kg} / \mathrm{ha}$ to the highfertility plots in November 1999. Plots were irrigated regularly over summer using a soil water budget based on weekly rainfall and evapotranspiration data.

Shorn Coopworth ewe lambs, stratified for liveweight $(32 \pm 7 \mathrm{~kg})$, were allocated to eight flocks in February of each year. Each flock rotationally grazed a 0.16 ha farmlet of four plots of the same treatment from September 1998 to June 1999 in year 2 and from September 1999 to May 2000 in year 3. Rotations were short in spring/early summer ( $16 \pm 2$ days) and long ( $28 \pm 2$ days) in late summer/autumn to provide a grazing management strategy suitable for both clovers (Lucas et al. 1998). Plots were not grazed in winter. Stocking rate averaged 45 sheep/ha and was adjusted using a putand-take method at each weighing to achieve similar pasture allowances for all flocks $(2.4 \mathrm{~kg} \mathrm{DM} / \mathrm{hd} / \mathrm{d}$ in year 2 and $2.6 \mathrm{~kg} \mathrm{DM} / \mathrm{hd} / \mathrm{d}$ in year 3). Anthelmintic drenches and pour-on dip were administered when necessary to control sheep parasites. Pastures were topped in late spring-summer to reduce ryegrass and annual grass (barley grass (Hordeum spp.) and goose grass (Bromus hordeaceus syn B. mollis)) seedheads in pastures.

\section{Measurements}

Pre- and post-grazing pasture masses were measured using a capacitance meter. The capacitance meter was calibrated against five dry matter (DM) cuts of both pre- and post-grazing pasture mass per treatment and re-calibrated in each 'pasture season' according to L'Huillier \& Thomson (1988). Pre- and post-grazing legume contents were determined by dissecting a subsample of bulked, mixed herbage from 20 random cuts per plot. Legume and grass components sampled in the autumns of 1998 and 1999 were analysed for crude protein (CP) and organic matter digestibility (OMD).
Sheep were weighed before and after every second rotation in spring/early summer and each rotation in late summer/autumn. Sheep were not weighed from 23 December 1998 to 2 March 1999 but grazing days (Gd) per farmlet (mean $382 \mathrm{Gd}$ ) were recorded.

Dry matter production and legume content were measured independently of the grazing sheep within one caged area per plot over 20 growth periods of $28 \pm 2$ days from September 1998 to June 2000. New areas to be excluded from grazing were mown to 30 $\mathrm{mm}$ at the start of each 28-day period. After every period, herbage within one $0.2 \mathrm{~m}^{2}$ quadrat per plot was cut to $30 \mathrm{~mm}$ above ground level and sub-samples from these cuts were dissected to determine botanical composition before drying.

\section{Statistical analysis}

Significant $(\mathrm{P}<0.05)$ agronomic treatment differences were determined using two-way analysis of variance according to the Latin square design. Liveweight gain differences were determined according to the $2^{2}$ factorial design for the two animal replicates.

\section{Results}

\section{Pasture mass and grazing days}

Pre-grazing pasture mass in year 2 was similar across all four treatments and averaged $2210 \mathrm{~kg} \mathrm{DM} / \mathrm{ha}$ (Table 2). The mean pasture mass on offer in year 3 was also similar between clover treatments, but greater $(\mathrm{P}<0.05)$ in high-fertility rather than low-fertility pastures (2490 vs. $2330 \mathrm{~kg} \mathrm{DM} / \mathrm{ha})$. Post-grazing pasture mass averaged $1240 \mathrm{~kg} \mathrm{DM} / \mathrm{ha}$ in year 2 and $1330 \mathrm{~kg} \mathrm{DM} / \mathrm{ha}$ in year 3. Total grazing days per farmlet in year 2 averaged $1535 \mathrm{Gd}$. In year 3 , the sum of grazing days was similar between clover treatments, but greater $(\mathrm{P}<0.05)$ from high- than low-fertility farmlets (1543 vs. $1454 \mathrm{Gd})$.

\section{Pasture legume content}

Caucasian clover pastures had a higher $(\mathrm{P}<0.05)$ pregrazing legume content than pastures sown with white clover in year $2(26 \%$ vs. $17 \%)$ and year $3(19 \%$ vs. $12 \%$ ) (Table 2). Legume content was similar between fertility treatments in both years. Of the percentage of legume on offer in the caucasian clover pastures in year 3,39\% was identified as volunteer white clover.

Table 1 Soil Quick Test means from the 26 May 1998 sampling of four high-fertility (plus fertiliser) and four low-fertility (no fertiliser) farmlets.

\begin{tabular}{llllrrrr}
\hline & $\mathrm{pH}$ & $\mathrm{Ca}$ & $\mathrm{K}$ & Olsen P & $\mathrm{Mg}$ & $\mathrm{Na}(\mathrm{SO})$ \\
\hline High-fertility & 6.1 & 10 & 13 & 22 & 14 & 23 & 10 \\
Low-fertility & 6.3 & 10 & 15 & 10 & 27 & 13 & 9 \\
\hline
\end{tabular}


Table 2 Mean pre- and post-grazing pasture masses ( $\mathrm{kg} \mathrm{DM} / \mathrm{ha})$, grazing days per farmlet, pre-grazing legume content (\%), and sheep liveweight gain (kg/ha/yr) from caucasian and white clover pastures at high- (plus fertiliser) and low-fertility (no fertiliser) during year 2 (September 1998 to May 1999) and year 3 (September 1999 to May 2000).

\begin{tabular}{|c|c|c|c|c|c|}
\hline Treatment & $\begin{array}{l}\text { Pre-grazing mass } \\
(\mathrm{kg} \mathrm{DM} / \mathrm{ha})\end{array}$ & $\begin{array}{l}\text { Post-grazing mass } \\
(\mathrm{kg} \mathrm{DM} / \mathrm{ha})\end{array}$ & Grazing days & $\begin{array}{l}\text { Pre-grazing } \\
\text { legume content } \\
(\%)\end{array}$ & $\begin{array}{c}\text { Liveweight } \\
\text { gain* }(\mathrm{kg} / \mathrm{ha} / \mathrm{yr})\end{array}$ \\
\hline & 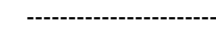 & ------ & --- Year 2 - & 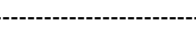 & - \\
\hline $\begin{array}{l}\text { Caucasian clover } \\
\text { White clover }\end{array}$ & $\begin{array}{l}2160 \\
2260\end{array}$ & $\begin{array}{l}1220 \\
1260\end{array}$ & $\begin{array}{l}1514 \\
1556\end{array}$ & $\begin{array}{l}26 \\
17\end{array}$ & $\begin{array}{l}1110 \\
1140\end{array}$ \\
\hline $\begin{array}{l}\text { High-fertility } \\
\text { Low-fertility }\end{array}$ & $\begin{array}{l}2230 \\
2190\end{array}$ & $\begin{array}{l}1240 \\
1240\end{array}$ & $\begin{array}{l}1539 \\
1530\end{array}$ & $\begin{array}{l}22 \\
21\end{array}$ & $\begin{array}{l}1150 \\
1110\end{array}$ \\
\hline SEM & 35 & 22 & 7.1 & 0.6 & 11 \\
\hline $\begin{array}{l}\text { Caucasian clover } \\
\text { White clover }\end{array}$ & $\begin{array}{l}2420 \\
2400\end{array}$ & $\begin{array}{l}1310 \\
1350\end{array}$ & $\begin{array}{l}1507 \\
1490\end{array}$ & $\begin{array}{l}19 \\
12\end{array}$ & $\begin{array}{l}1290 \\
1110\end{array}$ \\
\hline $\begin{array}{l}\text { High-fertility } \\
\text { Low-fertility }\end{array}$ & $\begin{array}{l}2490 \\
2330\end{array}$ & $\begin{array}{l}1350 \\
1310\end{array}$ & $\begin{array}{l}1543 \\
1454\end{array}$ & $\begin{array}{l}14 \\
15\end{array}$ & $\begin{array}{l}1230 \\
1160\end{array}$ \\
\hline SEM & 30 & 19 & 4.5 & 0.8 & 4 \\
\hline
\end{tabular}

*Liveweight gain not recorded from December 1998 to March 1999 (mean 382 Gd)

Post-grazing pasture mass had a lower proportion of green clover and grass, and more dead material than in the pre-grazing pasture mass $(\mathrm{P}<0.05)$.

\section{Pasture nutritive value}

In the autumns of 1998 and 1999, the nutritive values of clover species were similar (caucasian clover: $28.5 \%$ $\mathrm{CP}$ and $85.2 \%$ OMD vs. white clover: $28.3 \% \mathrm{CP}$ and $86.2 \% \mathrm{OMD})$. However, the nutritive value of ryegrass from caucasian $(22.0 \% \mathrm{CP}$ and $80.2 \% \mathrm{OMD}$ ) and white (23.1\% CP and $81.5 \% \mathrm{OMD}$ ) clover pastures differed $(\mathrm{P}<0.05)$, but was similar between fertility treatments.

\section{Liveweight gain}

Sheep liveweight gains in year 2 were similar across all four treatments during spring $(170 \mathrm{~g} / \mathrm{hd} / \mathrm{d})$ and autumn $(127 \mathrm{~g} / \mathrm{hd} / \mathrm{d})$ and averaged $1130 \mathrm{~kg} / \mathrm{ha} / \mathrm{yr}$ (Table 2). However in year 3 , sheep grew faster $(\mathrm{P}<0.05)$ on pastures sown with caucasian than white clover $(1290$ vs. $1110 \mathrm{~kg} / \mathrm{ha} / \mathrm{yr}$ ). Liveweight gains per head per day were greater $(\mathrm{P}<0.05)$ from sheep grazing caucasian than white clover pastures in spring (180 vs. $160 \mathrm{~g} / \mathrm{hd} /$ d) and autumn (124 vs. $112 \mathrm{~g} / \mathrm{hd} / \mathrm{d})$, but were similar in summer $(81 \mathrm{~g} / \mathrm{hd} / \mathrm{d})$ when mean liveweight of ewe hoggets was $60 \pm 8 \mathrm{~kg}$. More $(\mathrm{P}<0.05)$ liveweight per hectare was produced on high- than low-fertility farmlets (1230 vs. $1160 \mathrm{~kg} / \mathrm{ha} / \mathrm{yr}$ ) because of the higher carrying capacity of high-fertility farmlets. Liveweight gains per head per day were similar between fertility treatments.

\section{Dry matter production from 28-day harvests}

Total DM production after 10 months in year 2 (September 1998 to June 1999) was similar across all
Table 3 Total dry matter production (t DM/ha) and mean legume content (\%) from caucasian and white clover pastures at high- (plus fertiliser) and low-fertility (no fertiliser) during year 2 (September 1998 to June 1999) and year 3 (July 1999 to June 2000).

\begin{tabular}{|c|c|c|c|c|}
\hline \multirow[t]{2}{*}{ Treatment } & \multicolumn{2}{|c|}{----- Year 2 ----- } & \multicolumn{2}{|c|}{---- Year 3} \\
\hline & $\begin{array}{c}\text { Total } \\
\text { yield } \\
\text { (t DM/ha) }\end{array}$ & $\begin{array}{c}\text { Legume } \\
\text { content } \\
(\%)\end{array}$ & $\begin{array}{c}\text { Total } \\
\text { yield } \\
\text { (t DM/ha) }\end{array}$ & $\begin{array}{l}\text { Legume } \\
\text { content } \\
\quad(\%)\end{array}$ \\
\hline Caucasian clover & 16.6 & 29 & 16.8 & 21 \\
\hline White clover & 16.1 & 18 & 16.2 & 13 \\
\hline $\begin{array}{l}\text { High-fertility } \\
\text { Low-fertility }\end{array}$ & $\begin{array}{l}16.8 \\
15.9\end{array}$ & $\begin{array}{l}24 \\
24\end{array}$ & $\begin{array}{l}17.3 \\
15.7\end{array}$ & $\begin{array}{l}15 \\
19\end{array}$ \\
\hline SEM & 0.35 & 0.8 & 0.23 & 0.9 \\
\hline
\end{tabular}

four treatments and averaged $16.3 \mathrm{t} \mathrm{DM} / \mathrm{ha}$ (Table 3). Production was also similar between clover treatments after 12 months in year 3 (July 1999 to June 2000), but was greater $(\mathrm{P}<0.05)$ from high- than low-fertility pastures (17.3 vs. 15.7 t DM/ha).

Pasture production rates in year 2 were similar across all four treatments and averaged $63 \mathrm{~kg} / \mathrm{ha} / \mathrm{d}$ (Figure 1). However in year 3, caucasian clover pastures had a higher $(\mathrm{P}<0.05)$ mean production rate than pastures sown with white clover (58 vs. $55 \mathrm{~kg} \mathrm{DM} / \mathrm{ha} /$ d). Production rates in November 1998 averaged $98 \mathrm{~kg}$ $\mathrm{DM} / \mathrm{ha} / \mathrm{d}$ from all treatments, and in May 1999 dropped to $27 \mathrm{~kg} \mathrm{DM} / \mathrm{ha} / \mathrm{d}$ for white clover compared with $18 \mathrm{~kg} \mathrm{DM} / \mathrm{ha} / \mathrm{d}$ for caucasian clover $(\mathrm{P}<0.05)$. In February 2000, caucasian clover pastures reached $90 \mathrm{~kg}$ $\mathrm{DM} / \mathrm{ha} / \mathrm{d}$ compared with $75 \mathrm{~kg} / \mathrm{ha} / \mathrm{d}$ for white clover $(\mathrm{P}<0.05)$, but in May 2000 dropped to $11 \mathrm{~kg} \mathrm{DM} / \mathrm{ha} / \mathrm{d}$ 
compared with $15 \mathrm{~kg} \mathrm{DM} / \mathrm{ha} / \mathrm{d}$ for white clover $(\mathrm{P}<0.05)$. Over both years, high-fertility pastures had a higher $(\mathrm{P}<0.05)$ mean production rate than lowfertility pastures (62 vs. $58 \mathrm{~kg} \mathrm{DM} / \mathrm{ha} / \mathrm{d})$.

\section{Legume content from 28-day harvests}

Caucasian clover pastures produced more $(\mathrm{P}<0.05)$ legume than pastures sown with white clover during year $2(29 \%$ vs. $18 \%)$ and year $3(21 \%$ vs. $13 \%)$ (Table 3). Specifically, more $(\mathrm{P}<0.05)$ legume was produced in caucasian than in white clover pastures between October and May of each year (Figure 2). In December 1998, caucasian clover pastures reached 40\% legume compared with $28 \%$ for white clover $(\mathrm{P}<0.05)$, but in June 1999 dropped to $4 \%$ legume compared with $6 \%$ for white clover $(\mathrm{P}<0.05)$. Similarly in year 3 , caucasian clover pastures reached $34 \%$ legume in January 2000 compared with $21 \%$ for white clover $(\mathrm{P}<0.05)$, before both treatments dropped to $3 \%$ legume in June 2000. Of the total legume produced in caucasian clover pastures in year 3, 41\% was identified as volunteer white clover. Legume content was similar across fertility treatments in year $2(24 \%)$, but lower $(\mathrm{P}<0.05)$ in high- than low-fertility pastures in year 3 (15\% vs. $19 \%$ ) (Table 3 ).

\section{Discussion}

The percentage of legume required to have any significant effect on animal performance is generally considered to be much higher than the current low average of 10-20\% found in many New Zealand white clover/ryegrass pastures (Caradus et al. 1996; Chapman et al. 1995). Thomson (1984) recommended that a mixed pasture should contain at least $30 \%$ legume, while Harris et al. (1997) showed summer pasture legume contents of $50-65 \%$ are required to achieve near maximum, per cow, milk production. In our experiment, caucasian clover pastures showed potential to approach these target legume contents, particularly in summer when legume content averaged $38 \%$ compared with only $25 \%$ for white clover (Figure 2 ).

Moss et al. (1996) demonstrated higher legume contents (28\% vs. $10 \%)$ and greater dry matter production (15 vs. $12 \mathrm{t} \mathrm{DM} / \mathrm{ha}$ ) from 3-year-old caucasian clover/ryegrass rather than white clover/ ryegrass pastures in an irrigated fertile environment at Winchmore, Canterbury. In our experiment, vigorous caucasian clover growth did not significantly enhance total dry matter production, and annual yields of at least $16 \mathrm{t} \mathrm{DM} / \mathrm{ha}$ were reached from both clover treatments. This may be attributed to the greater competitiveness of caucasian clover against perennial ryegrass, which resulted in lower grass yields from
Figure 1 Dry matter production rates (kg DM/ha/d) from caucasian $(\bullet)$ and white $(\mathrm{O})$ clover pastures during year 2 (September 1998 to June 1999) and year 3 (July 1999 to June 2000). Vertical bars represent one standard error of the mean.

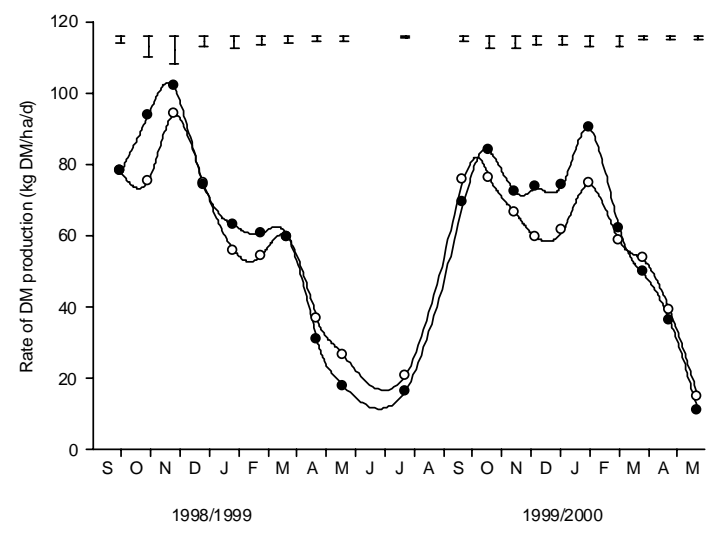

Figure 2 Total legume contents (\%) in caucasian (๑) and white (O) clover pastures during year 2 (September 1998 to June 1999) and year 3 (July 1999 to June 2000). Vertical bars represent one standard error of the mean.

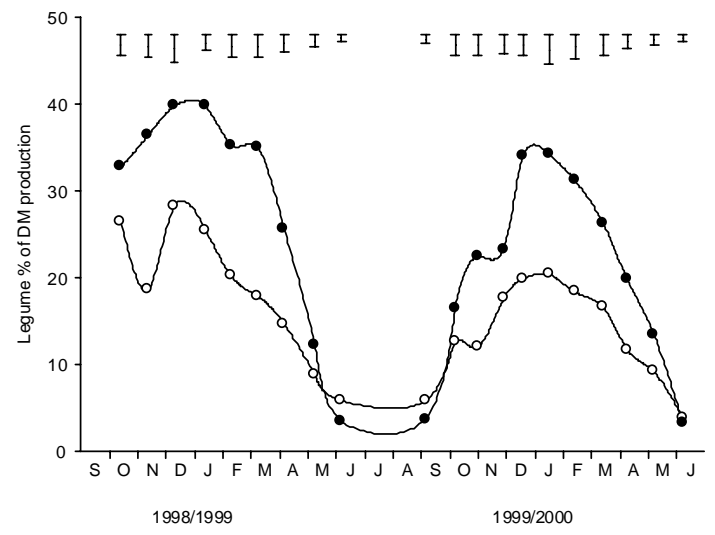

caucasian than from white clover pastures (11 vs. $12 \mathrm{t}$ $\mathrm{DM} / \mathrm{ha}$ ).

White clover demonstrated its greater cool season activity in early spring and late autumn while caucasian clover was more vigorous than white clover in summer. This can be partially explained by earlier findings, which describe caucasian clover as having a higher base temperature $\left(4.2^{\circ} \mathrm{C}\right)$ and thermal time requirement or phyllocron $\left(279^{\circ} \mathrm{Cd}\right)$ for leaf appearance than white clover $\left(3.1^{\circ} \mathrm{C}, 173^{\circ} \mathrm{Cd}\right)$ (Black 1998$)$.

The total legume content of caucasian clover pastures in the third year contained a noticeable proportion of volunteer white clover (probably 'Huia') arising from hard seed surviving in the soil for 16 
years since the area was last in permanent pasture. This mixture of the two clover species represents what is most likely to happen even where caucasian clover is sown without white clover because of the widespread presence of white clover seed in New Zealand pastoral land. Elliot et al. (1998) discussed the possibility of poor sociability between caucasian and white clover because of rhizobial incompatibility. However, in this and other experimental sowings (e.g., Black \& Lucas 2000; Moss et al. 1996; Watson et al. 1996b), caucasian clover has appeared to be complementary rather than competitive towards white clover.

Liveweight gains from lambs grazing all four treatments were within the expected range for perennial ryegrass-dominant pasture with 10-30\% legume (Askin et al. 1987; Ryan \& Widdup 1997). The relatively low pasture allowances and the use of ewe lambs would have limited liveweight gain potential. In contrast, the use of zero endophyte 'Ruanui' ryegrass and the maintenance of a high proportion of green leaf material in the pastures ensured herbage of high nutritive value. In addition, caucasian and white clover forage had similar high nutritive values, which supports similar findings by Allinson et al. (1985). Animal disorders and production depressions associated with wild-type endophyte from infected ryegrass (Fletcher et al. 1999) were also avoided by the use of zero-endophyte ryegrass.

The relatively low pasture allowance and pre- and post-grazing pasture masses in year 2 would have limited our ability to convert the higher total legume content on offer in the caucasian clover pastures into a significant difference in liveweight gain. In contrast, the significant difference in liveweight gain between clover treatments in the third year may have been assisted by the slightly greater pasture allowance on offer and greater pre- and post-grazing pasture masses. This could have presented increased opportunities for clover selection by the sheep (Askin et al. 1987).

While this paper is focused on pasture production, legume composition and sheep liveweight gain, it should be noted that both clovers established successfully from an early December sowing and the use of appropriate post-emergence herbicides. The direct-drilling with ryegrass 4 months later in March was more successful in caucasian than white clover plots partly because the white clover stolons presented more resistance to the drill coulters but also because white clover was more active than caucasian clover as temperatures declined through April and May. This sowing strategy has also been successful in other experimental sowings (e.g., Watson et al. 1996b).

The small differences in pasture and animal performance between fertility treatments indicated that the initial soil fertility was adequate for sheep production from pasture. It is anticipated that these responses will become more obvious in subsequent years as soil fertility in the low-fertility treatments slowly declines while the high-fertility treatments are maintained at Olsen $\mathrm{P}>20$ and sulphate-S $>8$. There may be a decline in legume content in the white cloverplus-fertiliser treatment as soil nitrogen builds up and ryegrass becomes more competitive. It remains to be seen if caucasian clover can maintain its vigour against ryegrass as soil nitrogen increases over time. If this interaction is demonstrated it will provide a strong incentive to sow caucasian clover in pastures which are designed to last more than about 6 years.

\section{Conclusions}

The preliminary results from this ongoing comparison of caucasian with white clover in ryegrass pastures, showed that caucasian clover can make a significant contribution to lowland livestock production systems. Specific conclusions were:

1. Excellent caucasian clover/ryegrass pastures can be established by sowing caucasian clover in spring and direct-drilling the ryegrass in the following autumn.

2. Caucasian clover/ryegrass pastures plus volunteer white clover have higher total legume contents than white clover/ryegrass pastures.

3. Increased sheep liveweight gains can be demonstrated from pastures with enhanced total legume content.

\section{ACKNOWLEDGEMENTS}

The C. Alma Baker and Struthers Trusts for providing A.D. Black with financial support from post-graduate scholarships.

\section{REFERENCES}

Allan, B.E.; Keoghan, J.M. 1994. More persistent legumes and grasses for oversown tussock country. Proceedings of the New Zealand Grassland Association 56: 143-147.

Allinson, D.W.; Speer, G.S.; Taylor, R.W.; Guillard, K. 1985. Nutritional characteristics of Kura clover (Trifolium ambiguum M. Bieb) compared with other forage legumes. Journal of Agricultural Science 104: 227-229.

Askin, D.C; Pownall, D.B.; Lucas, R.J. 1987. The effects of clover content and herbage mass on lamb growth rate in autumn. pp. 233-234. In: Herbivore nutrition 
research. Ed. Rose, M. Occasional Publication of Australian Society of Animal Production.

Black, A.D. 1998. Cool season performance of Caucasian clover and white clover in perennial ryegrass pastures. Honours Dissertation. Lincoln University.

Black, A.D.; Lucas, R.J. 2000. Caucasian clover was more productive than white clover in grass mixtures under drought conditions. Proceedings of the New Zealand Grassland Association 62: 183-188.

Caradus, J.R.; Harris, S.L.; Johnson, R.J. 1996. Increased clover content for increased milk production. Proceedings of the Ruakura Farmers' Conference 48: 42-49.

Chapman, D.F.; Parsons, A.J.; Schwinning, S. 1995. Management of clover in grazed pastures: expectations, limitations and opportunities. White Clover: New Zealand's Competitive Edge. Agronomy Society of New Zealand Special Publication 11/Grassland Research and Practice Series 6: 55-64.

Elliot, R.M.; McIntyre, H.J.; Challis, B.C., Pryor, H.N.; Lowther, W.L.; Ronson, C.W. 1998. Rhizobium issues affecting the contribution of caucasian clover to New Zealand pastoral agriculture. Proceedings of the New Zealand Grassland Association 60: 207211.

Fletcher, L.R.; Sutherland, B.L.; Fletcher, C.G. 1999. The impact of endophyte on the health and productivity of sheep grazing ryegrass-based pastures. Ryegrass Endophyte: An Essential New Zealand Symbiosis. Grassland Research and Practice Series 7: 11-17.

Harris, S.L.; Clark, D.A.; Auldist, M.J.; Waugh, C.D.; Laboyrie, P.G. 1997. Optimum white clover content for dairy pastures. Proceedings of the New Zealand Grassland Association 59: 29-33.

Hill, M.J.; Hockney, M.J.; Mulcahy, C.A.; Rapp, G. 1995. The effect of hydrogen cyanide potential $(\mathrm{HCNp})$ and sward morphology on the relative acceptability to sheep of white clover and Caucasian clover herbage. Grass and Forage Science 50: 1-9.

L'Huillier, P.J.; Thomson, N.A. 1988. Estimation of herbage mass in ryegrass-white clover dairy pastures. Proceedings of the New Zealand Grassland Association 49: 117-122.

Lucas, R.J.; Moorhead, A.J.E.; Nichol, W.W.; Jarvis, P. 1998. Frequent grazing by sheep reduced Caucasian clover cover and rhizome mass in ryegrass pasture. Proceedings of the New Zealand Grassland Association 60: 203-206.
Moss, R.A.; Burton, R.N.; Allan, B.E. 1996. Productivity of Caucasian clover based pastures under irrigation. Proceedings of the New Zealand Grassland Association 58: 177-181.

Pryor, H.N.; Lowther, W.L.; McIntyre, H.J.; Ronson, C.W. 1998. An inoculant Rhizobium strain for improved establishment and growth of hexaploid Caucasian clover (Trifolium ambiguum). New Zealand Journal of Agricultural Research 41: 179189.

Ryan, D.L.; Widdup, K.H. 1997. Lamb and hogget growth on different white clover and ryegrass cultivar mixtures in southern New Zealand. Proceedings of the New Zealand Society of Animal Production 57: 182-185.

Scott, D. 1998. Sixteen years of caucasian clover under contrasting managements. Proceedings of the New Zealand Grassland Association 60: 115-118.

Sheaffer, C.C.; Marten, G.C.; Jordan, R.M.; Ristau, E.A. 1992. Forage potential of Kura clover and birdsfoot trefoil when grazed by sheep. Agronomy Journal 84: 176-180.

Stevens, D.R.; Casey, M.J.; Baxter, G.S.; Miller, K.B. 1993. A response of angora-type goats to increases of legume and chicory content in mixed pastures. Proceedings of the XVII International Grassland Congress 1993: 1300-1301.

Thomson, D.J. 1984. The nutritive value of white clover. Forage Legumes. Occasional Symposium of the British Grassland Society 16: 78-92.

Watson, R.N.; Neville, F.J.; Bell, N.L. 1996a. Insect pests associated with white and caucasian clover in a Bay of Plenty dairy pasture. Proceedings of the New Zealand Plant Protection Conference 49: 234238.

Watson, R.N.; Neville, F.J.; Bell, N.L. 1998. Caucasian clover performance in a year of severe drought. Proceedings of the New Zealand Grassland Association 60: 119-125.

Watson, R.N.; Neville, F.J.; Bell, N.L.; Harris, S.L. 1996b. Caucasian clover as a pasture legume for dryland dairying in the coastal Bay of Plenty. Proceedings of the New Zealand Grassland Association 58: 183-188.

Woodman, R.F.; Keoghan, J.M.; Allan, B.E. 1992. Pasture species for drought-prone lower slopes in the South Island high country. Proceedings of the New Zealand Grassland Association 54: 115-120. 